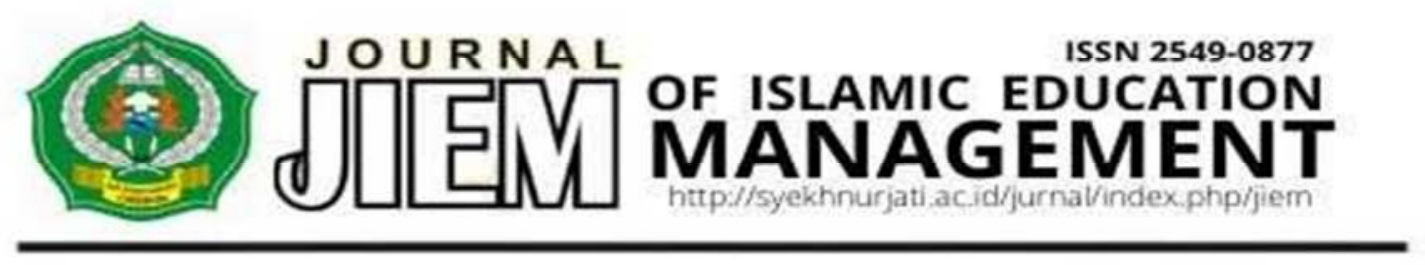

\author{
PENGELOLAAN SARANA DAN PRASARANA DALAM MENINGKATKAN \\ PROSES PEMBELAJARAN PESERTA DIDIK DI DINIYAH TAKMILIYAH \\ AWWALIYAH AL-FURQON DESA PANIIS \\ KECAMATAN PASAWAHAN KABUPATEN KUNINGAN
}

\title{
MANAGEMENT OF FACILITIES AND INFRASTRUCTURE IN IMPROVING THE LEARNING PROCESS OF STUDENTS AT DINIYAH TAKMILIYAH AWWALIYAH AL-FURQON, PANIIS VILLAGE
}

\author{
Dewi Amanda Putri, Ahmad Ripai, Ahmad Amin Mubarak. \\ Institut Agama Islam Negeri (IAIN) Syekh Nurjati Cirebon \\ dewiamandap@gmail.com ahmadripai@syekhnurjati.ac.id, \\ ahmadaminmubarok@gmail.com
}

\begin{abstract}
The facilities and infrastructure owned by Diniyah Takmiliyah Awwaliyah Al-Fur-qon Paniis Village can be said to be lacking because there is still a shortage of classrooms in learning, there are still those who study in the prayer room. In fulfilling the facilities in the classroom, learning activities are very influential for students such as the completeness of tools and preparation for learning.

The management of facilities and infrastructure in improving the learning process in Diniyah Takmiliyah Awwaliyah Al-Fur-qon Paniis Village includes planning, organizing, procurement and supervision. To conduct a selection of the items to be used, it means that the manager checks the items that support the learning process, to avoid unwanted mistakes.

The teacher's efforts are made to improve the learning process of students at Diniyah Takmiliyah Awwaliyah Al-Fur-qon Paniis Village, the teacher's obstacles in improving the learning process of students are limited facilities and infrastructure that are less supportive, problems for students can also be seen from their family factors themselves, because most of them do not live with their parents but with their grandparents, so the lack of parental supervision and upbringing is like student discipline, resulting in obstacles in improving the learning process in madrasas.

Supporting and inhibiting factors in improving the learning process of students in Diniyah Takmiliyah Awwaliyah Al-Fur-qon Paniis Village, as for the supporting factors, one of which is the teacher, the teacher's role is very important for the learning process, because professionalism will determine success during the learning process. teaching and learning in the classroom. Meanwhile, environmental problems in the inhibiting factors of the learning process usually occur in students, namely the lack of interest of students in the learning process. This is because it was found that some students were still outside while studying,
\end{abstract}


while in the classroom there were still noise, there were also students who were nosy with their friends in the class. The process of increasing at Al-Furqon DTA can be seen from the number of students who enter every year.

Keywords : Management of Facilities and Infrastructure, Learning Process

\begin{abstract}
Abstrak
Sarana dan prasarana yang di miliki Diniyah Takmiliyah Awwaliyah Al-Fur-qon Desa Paniis dapat dikatakan kurang karena masih kekurangan ruang kelas dalam pembelajaran, masih ada yang belajar di mushola. Dalam pemenuhan sarana di dalam kelas kegiatan pembelajaran sangat berpengaruh bagi peseta didik seperti kelengkapan alat dan persiapan pembelajaran. Pengelolaan sarana dan prasarana dalam meningkatkan proses pembelajaran di Diniyah Takmiliyah Awwaliyah Al-Fur-qon Desa Paniis terdapat perencanaan, pengorganisasian, pengadaan dan pengawasan. Untuk mengadakan seleksi terhadap barang yang akan dimanfaatkan maksudnya pengelola melakukan pengecekan terhadap barang-barang yang menunjang berjalannya suatu pembelajaran, untuk menghindari kesalahan yang tidak diinginkan. Upaya Guru yang di lakukan untuk meningkatkan proses pembelajaran peserta didik di Diniyah Takmiliyah Awwaliyah Al-Fur-qon Desa Paniis, hambatan guru dalam meningkatkan proses pembelajaran peserta didik yaitu keterbatasan sarana dan prasarana yang kurang mendukung, permasalahan pada santri juga bisa dilihat dari faktor keluarga nya sendiri, karena kebanyakan dari mereka tidak tinggal dengan orang tua mereka melainkan dengan kakek dan nenek mereka, jadi kurangnya pengawasan dan didikan orang tua nya seperti kedisiplinan santri, sehingga mengakibatkan hambatan-hambatan dalam meningkatkan proses pembelajaran di madrasah. Faktor pendukung dan penghambat dalam meningkatkan proses pembelajaran peserta didik di Diniyah Takmiliyah Awwaliyah Al-Furqon Desa Paniis, adapun faktor pendukung nya salah satunya pada guru, peran guru lah sangat penting bagi proses pembelajaran, karena keprofesionalitas lah akan menentukan suatu keberhasilan pada saat proses belajar mengajar di dalam kelas. Sedangkan permasalahan lingkungan dalam faktor penghambat proses pembelajaran biasanya terjadi pada peserta didik yaitu kurangnya minat santri dalam proses pembelajaran. Hal ini karena ditemukan ada beberapa santri pada saat belajar ada yang masih diluar, ketika di dalam kelas masih ada yang ribut, ada juga santri yang usil dengan teman-teman di dalam kelas. Proses meingkatnya di DTA Al-Furqon bisa dilihat dari peserta didik yang masuk setiap tahunnya bertambah.
\end{abstract}

Kata kunci : Pengelolaan Sarana dan Prasarana, Proses Pembelajaran

\section{PENDAHULUAN}

Sebuah instansi pendidikan baik
formal maupun non formal pasti
membutuhkan penunjang proses
pembelajaran diantaranya sarana dan
prasarana. Sarana adalah segala sesuatu
yang bisa di pakai sebagai alat untuk
mencapai suatu tujuan pendidikan.
Sedangkan prasarana merupakan
penunjang utama terlaksananya proses
pembelajaran di lembaga pendidikan.

Pengelolaan sarana dan prasarana sangat penting bagi suatu lembaga, karena sangat mendukung ke efektivan proses pembelajaran.

$$
\text { Dalam Undang-Undang }
$$

Pendidikan Nasional disebutkan bahwa pendidikan non formal diselenggarakan bagi warga masyarakat yang membutuhkan layanan pendidikan berfungsi sebagai pengganti, penambah, dan atau pelengkap dari pendidikan formal. 
Sementara itu dalam PP no. 55 tahun 2007 tentang Pendidikan Agama dan Keagamaan dijelaskan bahwa Pendidikan Madrasah Diniyah Takmiliyah merupakan pendidikan keagamaan non formal yang keberadaannya tumbuh dan perkembangan di masyarakat.

Kebijakan pemerintah tentang pengelolaan sarana dan prasarana sekolah tertuang di dalam UU No. 20 tahun 2003 tentang Sisdiknas pasal 45 ayat (1) yaitu "Setiap satuan pendidikan formal dan non formal menyediakan sarana dan prasarana yang memenuhi keperluan pendidikan sesuai dengan pertumbuhan dan perkembangan potensi fisik, kecerdasan intelektual, social, emosional dan kejiwaan peserta didik.

Salah satu aspek dari setiap administrasi pendidikan yaitu sarana dan prasarana pendidikan. Secara etimologis sarana yaitu alat yang dapat dipakai secara langsung untuk mencapai tujuan pendidikan. Sarana pendidikan pada umumnya yaitu peralatan dan perlengkapan secara langsung digunakan dalam proses pembelajaran, seperti kursi, meja, papan tulis dan sebagainya (Januartiny, 2015).

Adapun yang dimaksud prasarana yaitu peralatan yang secara tidak langsung penunjang suatu proses pembelajaran, seperti ruang kelas, taman, ruang kantor, dan lain sebagainya (Januartiny, 2015). Jadi, dapat ditarik kesimpulan bahwa administrasi sarana dan prasarana pendidikan yaitu suatu proses penunjang jalannya pembelajaran baik secara langsung maupun tidak langsung untuk mencapai suatu tujuan pembelajaran.

Madrasah Diniyah adalah suatu madrasah yang seluruh mata pengajarannya mengenai ilmu-ilmu agama, seperti fiqih, aqidah akhlak, tauhid dan ilmu agama lainnya. Seiring dengan peningkatan kebutuhan pendidikan agama oleh masyarakat, Madrasah Diniyah terus berkembang pesat, salah satunya Madrasah Diniyah Non Formal ini dilatar belakangi suatu keinginan masyarakat mengenai pentingnya agama, yang paling utama yaitu dalam menghadapi sebuah tantangan masa kini dan masa depan tingkat kebutuhan suatu keberagamaan yang semakin maju.

Madrasah Diniyah adalah suatu pelengkap dari sekolah pendidikan formal yang hanya pendidikan agamanya diberikan kurang lebih 2 jam, agar lebih mendalam tingkat keberagamaan peserta didik maka diadakannya sebuah Madrasah Diniyah. Ada tiga jenjang Diniyah Takmiliyah Awaliyah yaitu untuk tingkat dasar (diniyah takmiliyah awaliyah) dengan masa belajar enam tahun, untuk tingkat menengah (diniyah takmiliyah awaliyah wustha) dengan masa belajar selama tiga tahun. Sedangkan pada pendidikan formal umum (SD/MI, SMP/MTS, dan SMA/SMK atau sederajat dapat menambah dan memperdalam wawasan pengetahuannya mengenai agama Islam. Salah satu syarat berhasilnya suatu proses pembelajaran yaitu tersedianya sarana dan prasarana pendidikan yang cukup. Sarana belajar yang menunjang suatu pembelajaran.

Berdasarkan hasil observasi di Diniyah Takmiliyah Awaliyah Al-Furqon yang beralamatkan Jln. Karang Anyar Rt. 03 Rw. 04 Dusun Pon Desa Paniis Kec. Pasawahan Kab.Kuningan, terdapat suatu permasalahan mengenai manajemen sarana dan prasarana yang ada di Diniyah Takmiliyah Awaliyah Al-Furqon yang mana bertahun-tahun berdiri tetapi tidak ada perubahan untuk menambah ruang kelas, dikarenakan kurangnya ruang kelas mushola dijadikan tempat belajar kelas 2, ruang kantor dijadikan tempat belajar, karena dilihat dari Sarana dan Prasarana nya tidak lengkap, jadi kurangnya kedisiplinan peserta didik dalam proses pembelajaran, sehingga peserta didik tidak nyaman melakukan pembelajaran dan membuat pembelajaran kurang efektif, juga adanya double job antara mengajar di Madrasah dan di Majelis Ta'lim, sehingga disaat ada jadwal mengajar di Madrasah 
Peserta Didik merasa kebingungan lalu digantikan terlebih dahulu oleh guru lain.

Suatu permasalahan yang terdapat di Diniyah Takmiliyah Awaliyah AlFurqon dalam hal pengelolaannya kurang maksimal, sehingga membuat penurunan terhadap proses pembelajaran menjadi kurang efektif. Ruang kelas belajar di Diniyah Takmiliyah Awaliyah Al-Furqon, dapat dikatakan kurang memadai karena jumlah ruang kelas hanya ada 4 kelas. Adapun kinerja Kepala Madrasah dalam mengelola sarana dan prasarana belum terlaksana dengan baik.

Sarana dan prasarana sangat berpengaruh bagi keberhasilan suatu lembaga terutama dalam proses pembelajaran, maka perlu adanya usaha dalam meningkatkan kualitas proses pembelajaran. Kualitas pendidikan dapat dilakukan dengan memperbaiki sarana dan prasarana yang ada di Madrasah tersebut. Peningkatan kualitas pendidikan dilakukan meliputi penggunaan sarana pembelajaran sebagai alat penunjang pembelajaran, sehingga peserta didik efektif dalam proses pembelajaran, dan mampu bersaing dalam mencapai kompetensi.

Kondisi sarana dan prasarana yang ada di Diniyah Takmiliyah Awaliyah AlFurqon yang belum memenuhi standardisasi, serta dalam pengelolaan pun masih belum maksimal, maka peranan pemerintah sangat dibutuhkan dalam peningkatan sarana dan prasarana, juga dibutuhkan suatu pengawasan agar dapat mempertimbangkan sejauh mana sarana dan prasarana tersebut dapat dikelola dan dimanfaatkan sesuai dengan pencapaian tujuan madrasah.

Dengan adanya masalah di atas, maka peneliti memiliki ketertarikan untuk menganalisis lebih lanjut mengenai "Pengelolaan Administrasi Sarana Dan Prasarana Dalam Meningkatkan Proses Pembelajaran Peserta Didik di Diniyah Takmiliyah Awwaliyah Al-Fur-qon Desa Paniis".

Seperti yang sudah di jelaskan dalam pembatasan masalah, maka terdapat suatu permasalahan yang dapat di rumuskan sebagai berikut:

1. Bagaimana sarana dan prasarana yang di miliki Diniyah Takmiliyah Awwaliyah Al-Fur-qon Desa Paniis?

2. Bagaimana pengelolaan sarana dan prasarana dalam meningkatkan proses pembelajaran di Diniyah Takmiliyah Awwaliyah Al-Fur-qon Desa Paniis?

3. Bagaimana upaya yang di lakukan guru untuk meningkatkan proses pembelajaran peserta didik di Diniyah Takmiliyah Awwaliyah Al-Fur-qon Desa Paniis?

4. Bagaimana faktor pendukung dan penghambat dalam meningkatkan proses pembelajaran peserta didik di Diniyah Takmiliyah Awwaliyah AlFur-qon Desa Paniis?

Berdasarkan rumusan masalah di atas, maka tujuan penelitian ini adalah untuk mengetahui sejauh mana pengelolaan sarana dan prasarana dalam meningkatkan proses pembelajaran di DTA Al-Furqon Desa Paniis Kec.Pasawahan Kab. Kuningan.

\section{METODE}

Penelitian ini di laksanakan di DTA Al-Furqon yang beralamatkan di Jln. Karang Anyar Rt.03 Rw.04 Desa Paniis Dusun Pon Kec. Pasawahan Kab. Kuningan. Informan dalam penelitian ini yaitu Kepala Madrasah, Guru/Ustadz dan Santri. Penelitian ini menggunakan metode kualitatif. (deskriptif), yang mana teknik ini ditempatkan sebagai cara untuk melakukan pengamatan secara langsung untuk menggali data yang akurat (Sugiyono, 2010: hlm 9). Adapun teknik pengumpulan data dalam penelitian ini yaitu observasi, wawancara dan dokumentasi.

Dalam penelitian ini peneliti melakukan secara langsung di lapangan yaitu di Diniyah Takmiliyah Awwaliyah AlFurqon. Penelitian ini melakukan observasi untuk mendapatkan semua informasi secara nyata yang berkaitan dengan sarana dan prasarana. Adapun 
wawancara yang peneliti lakukan di DTA Al-Furqon terkait bagaimana pengelolaan administrasi sarana dan prasarana yang di dalamnya berisi perencanaan, pengorganisasian, peng-adaan, pengawasan dan pengeva-luasian. Wawancara ini juga akan di lakukan kepada peserta didik terkait proses pembelajaran. Dan dokumentasi yang dapat digunakan misalnya catatan dan alat rekaman serta dokumentasi berupa gambar.

Adapun teknik analisis data dalam penelitian ini yaitu menggunakan pengumpulan data, reduksi data, penyajian data dan penarik kesimpulan. Juga adanya keabsahan data dalam penelitian ini menggunakan triangulasi sumber, triangulasi teknik dan triangulasi waktu.

\section{HASIL DAN PEMBAHASAN}

Pengelolaan sarana dan prasarana merupakan pengaturan yang dilakukan oleh semua rangkaian kegiatan lembaga pendidikan, dapat dikelola dengan baik, sehingga menciptakan proses pembelajaran yang kondusif.

a. Perencanaan Sarana dan Prasarana

Suatu lembaga pendidikan pasti membutuhkan administrasi, kegiatan administrasi yang baik harus diawali dengan sebuah perencanaan. Proses utama ini sangat penting untuk menghindari kesalahan yang tidak diinginkan. Dapat disimpulkan bahwa perencanaan sarana dan prasarana pendidikan merupakan suatu pekerjaan yang sulit dipecahkan, karena harus mempunyai kesiapan serta kemantapan dalam memulai suatu pekerjaan dalam rangka untuk menjadikan lembaga pendidikan menjadi lebih baik.

Dalam buku (Rusydi Ananda, 2017 : hlm 36) perencanaan memiliki arti rancangan atau kerangka dari suatu yang akan dilakukan pada masa depan. Salah satu usaha dalam meningkatkan proses pembelajaran yaitu ketersediaan sarana dan prasarana yang memadai, seperti hal nya membuat santri di madrasah itu merasa nyaman dalam belajar. Adapun langkah pertama yaitu suatu perencanaan yang dilakukan DTA Al-Furqon Desa Paniis ini berdasarkan analisis kebutuhan. Pertama, dilihat dari suatu kebutuhan madrasah, misalnya jumlah siswa. Tentu saja melakukan analisis terlebih dahulu karena sebuah analisis, kita disini tidak akan pernah tahu apa saja sarana dan prasarana yang dibutuhkan kedepannya

Dalam fasilitas di DTA Al-Furqon untuk mencapai suatu tujuan pendidikan. Sesudah di analisis maka madrasah melakukan perencanaan yang akan diajukan kepada Kepala Madrasah mengenai sarana dan prasarana apa saja yang diperlukan.

Dalam mengajukan masalah kebutuhan madrasah harus diajukan kepada Kepala Madrasah apa saja yang dibutuhkan, baru Kepala Madrasah menangani hal tersebut dan melakukan pengecekan dengan cara terjun langsung ke lapangan.

Untuk kelancaran dalam proses pembelajaran suatu lembaga pendidikan maka perlu memaksimalkan prasarana yang memadai, seperti penambahan ruang kantor, penambahan ruang kelas, untuk menambah ruang kelas, ruang kantor. Namun sebelumnya sudah ada ruang kantor, tetapi dilihat dari jumlah santri lumayan banyak, sampai saat ini ruang kantor masih digunakan menjadi ruang belajar kelas satu, dan belum pengadaan dalam perencanaan untuk menambah ruangan.

b. Pengorganisasian Sarana dan Prasarana

Menurut (Rohiat, 2012 : hlm 18) Organizing atau pengorganisasian diartikan sebagai suatu kegiatan membagi tugas kepada orang-orang yang terlibat di dalam kerjasama pendidikan, biasanya dilakukan dengan membuat struktur organisasi. Sedangkan menurut (Mustari, 2014 : hlm 8) organizing dikatakan sebagai semua aktivitas manajemen dalam mengelompokkan orang-orang yang 
terkait serta penetapan tugas, fungsi, wewenang serta tanggung jawab kepada masing-masing dengan tujuan terciptanya.

Sehingga dapat disimpulkan bahwa pengorganisasian atau organizing merupakan fase kedua setelah perencanaan (planning) yang harus dilaksanakan dan dikelola secara efektif dan efisien dalam rangka mencapai tujuan yang telah ditetapkan.

Dalam suatu lembaga atau sebuah organisasi agar suatu tujuan dapat tercapai maka dari itu lembaga harus bisa mengatur pengorganisasiannya seperti di madrasah sendiri yaitu kegiatan membagi tugas kepada guruguru yang terlibat dalam kerja sama madrasah. Madrasah sendiri dalam hal membagi tugas kepada wali kelas jadi di madrasah itu langsung kepada struktur organisasi yang didalamnya kepala madrasah, sekretaris dan bendahara, mengenai keuangan pembayaran biasanya santri membayar kepada wali kelas nya masing-masing setelah itu menghadap ke bendahara.

Pada masa pandemi ini, pihak madrasah mengajukan sebuah proposal mengenai bantuan operasional untuk madrasah yang bermaksud untuk mencegah siswa putus sekolah pada jenjang Madrasah Diniyah Takmiliyah di Kabupaten Kuningan, membantu siswa yang mengalami kesulitan.

\section{c. Pengadaan Sarana dan Prasarana}

Pengadaan sarana dan prasarana pendidikan merupakan suatu kegiatan pengadaan yang berupa alat dan barang sesuai dengan rencana yang telah tersusun secara sistematis. Pengadaan sarana dan prasarana dapat dilakukan dengan membuat sendiri, menyewa, meminjam dan membeli.

Pengadaan sarana dan prasarana pendidikan adalah suatu kegiatan penyediaan semua jenis sarana dan prasarana sesuai dengan kebutuhan suatu lembaga dalam rangka mencapai tujuan lembaga pendidikan itu sendiri yang telah direncakan sebelumnya. Dapat disimpulkan bahwa pengadaan sarana dan prasarana pendidikan yaitu suatu upaya yang dapat dilakukan dalam memenuhi kebutuhan suatu lembaga agar lancar dalam proses pendidikan dengan mengacu apa yang telah direncanakan.Setelah melaksanakan pengorganisasian tahap selanjutnya yaitu tahap pengadaan yang mana di dalam tahap ini harus disesuaikan dengan anggaran dan kebutuhan suatu madrasah. Pengadaan sarana dan prasarana pembelajaran merupakan suatu perencanaan yang telah disusun oleh pihak madrasah sebelumnya. Untuk meningkatkan proses pembelajaran peserta didik akan dipengaruhi oleh ketersediaan sarana dan prasarana yang dimiliki oleh DTA Al-Furqon Desa Paniis kondisi sarana dan prasarana di madrasah. Sarana dan prasarana dalam meningkatkan proses pembelajaran di DTA Al-Furqon masih kurang dalam pengadaannya, karena masih ada pembelajaran di mushola, yaitu pada pembelajaran kelas dua.

System pengadaan yang dapat dilakukan oleh DTA Al-Furqon yaitu sarana dan prasarana yang diusulkan oleh guru selanjutnya disetujui oleh Kepala Madrasah, karena dalam pengadaan sarana dan prasarana yang bertanggung jawab dalam hal pengadministrasian maupun keperluan pembelajaran yaitu Kepala madrasah.

Hal yang perlu diperhatikan dari tahap pengadaan ini yaitu dalam waktu, yang mana anggaran yang disiapkan oleh lembaga tersebut. Ada banyak cara yang bisa dilakukan dalam pengadaan sarana dan prasarana, antara lain membuat sendiri, menyewa, meminjam dan membeli. Tahun 2020 sampai sekarang ini cara yang digunakan oleh DTA AlFurqon adalah dengan mengajukan sebuah proposal.

Pada masa pandemi ini, pihak madrasah mengajukan sebuah proposal mengenai bantuan operasional untuk 
madrasah yang bermaksud untuk mencegah siswa putus sekolah pada jenjang Madrasah Diniyah Takmiliyah di Kabupaten Kuningan, membantu siswa yang mengalami kesulitan karena disebabkan oleh kondisi ekonomi, geografi, maupun alasan sosial lainnya untuk melanjutkan pendidikan, meningkatkan kualitas pembelajaran, meningkatkan kesejahteraan, motivasi mengajar, dan kinerja ustadz/guru. Dan untuk pembayaran setiap bulannya santri dipungut biaya sebesar Rp.15.000.”

\section{d. Pengawasan Sarana dan Prasarana}

Menurut (Werang, 2015 : hlm 148) pengawasan sarana dan prasarana merupakan suatu kegiatan yang secara langsung digunakan untuk kegiatan pengamatan, pemeriksaan, dan penilaian.

Hal ini untuk menghindari terjadinya penyimpangan dan penyalahgunaan. Sedangkan pengertian menurut (Soetjipto, 2009 : hlm 173) pengawasan harus didasarkan atas bukti-bukti yang nyata. Apabila pada saat pelaksanaan ternyata terdapat kekurangankekurangan, maka kepala sekolah harus bertindak dalam rangka memperbaiki dan menyelesaikannya.

Dapat disimpulkan bahwa dalam kegiatan pengawasan ini untuk memantau kegiatan dapat telaksana dengan baik atau tidak, serta membutuhkan sebuah perencanaan yang matang agar suatu tujuan pengawasan dapat dicapai secara efektif dan efisien.

Pengawasan dilakukan untuk mengoptimalkan pemanfaatan sarana dan prasarana di Madrasah. Pengawasan sendiri harus dilakukan secara objektif artinya bahwa pengawasan itu harus didasarkan pada bukti-bukti yang ada. Apabila dari hasil pengawasan terdapat kekurangan, maka Kepala Madrasah wajib melakukan tindakan-tindakan perbaikan dan penyelesaian.

Pengawasan sarana dan prasarana di DTA Al-Furqon dilakukan oleh guru/ustadz. Pengawasan terhadap sarana dan prasarana dengan cara mengadakan suatu pengamatan atau pemeriksaan pada santri.

Contohnya proses pembelajaran atau kegiatan yang lainnya di madrasah guru-guru selalu mengawasi santri nya tentang perkembangan dan kendala yang di hadapi pada saat kegiatan tersebut berlangsung. Semua perlengkapan pembelajaran disimpan di tempat penyimpanan dalam ruang kelas tersebut, dan setiap sudah habis pakai nya diadakan pengecekan ulang apakah barang tersebut masih bisa dipakai atau tidaknya. Di DTA Al-Furqon Desa Paniis pengelolaan sarana dan prasarna pembelajaran masih kurang optimal. Karena rasa yang kurang memiliki disetiap individu mengakibatkan sarana dan prasarana yang kurang di rawat dengan baik.

e. Pengevaluasian sarana dan prasarana

Setelah melakukan pengawasan, pengevaluasian juga harus dilaksanakan. Kegiatan evaluasi berhubungan dengan usaha dengan pengumpulan, pengelolaan, analisis serta penyajian data atau informasi untuk mengambil suatu keputusan (Sundjana, 2004 : hlm 254).

Mengingat pentingnya evaluating dalam sebuah lembaga pendidikan dimaksudkan untuk mengetahui program kegiatan. Dari kegiatan tersebut dapat membantu membuat sebuah keputusan.

Pengevaluasian yang dilakukan di madrasah yaitu pada saat selesai proses pembelajaran. Setelah melakukan tahap pengawasan, langkah selanjutnya yaitu pengevaluasian, agar dapat di pertimbangkan sebelum dan sesudah nya. Sebelum dan sesudahnya pembelajaran di wajibkan mempersiapkan apa yang akan dibutuhkan 
misalnya jadwal nya praktek, apa saja alat atau barang yang akan digunakan dalam praktek tersebut.

\section{SIMPULAN}

Berdasarkan penelitian dan pembahasan di atas, maka dapat diambil suatu kesimpulan sebagai berikut:

Sarana dan prasarana yang di miliki Diniyah Takmiliyah Awwaliyah AlFur-qon Desa Paniis dapat dikatakan kurang karena masih kekurangan ruang kelas dalam pembelajaran, masih ada yang belajar di mushola. Dalam pemenuhan sarana di dalam kelas kegiatan pembelajaran sangat berpengaruh bagi peseta didik seperti kelengkapan alat dan persiapan pembelajaran.

Pengelolaan sarana dan prasarana dalam meningkatkan proses pembelajaran di Diniyah Takmiliyah Awwaliyah Al-Furqon Desa Paniis terdapat perencanaan, pengorganisasian, pengadaan dan pengawasan. Untuk mengadakan seleksi terhadap barang yang akan dimanfaatkan maksudnya pengelola melakukan pengecekan terhadap barang-barang yang menunjang berjalannya suatu pembelajaran, untuk menghindari kesalahan yang tidak diinginkan.

Upaya Guru yang di lakukan untuk meningkatkan proses pembelajaran peserta didik di Diniyah Takmiliyah Awwaliyah Al-Fur-qon Desa Paniis, hambatan guru dalam meningkatkan proses pembelajaran peserta didik yaitu keterbatasan sarana dan prasarana yang kurang mendukung, permasalahan pada santri juga bisa dilihat dari faktor keluarga nya sendiri, karena kebanyakan dari mereka tidak tinggal dengan orang tua mereka melainkan dengan kakek dan nenek mereka, jadi kurangnya pengawasan dan didikan orang tua nya seperti kedisiplinan santri, sehingga mengakibatkan hambatanhambatan dalam meningkatkan proses pembelajaran di madrasah.

Faktor pendukung dan penghambat dalam meningkatkan proses pembelajaran peserta didik di Diniyah Takmiliyah
Awwaliyah Al-Fur-qon Desa Paniis, adapun faktor pendukung nya salah satunya pada guru, peran guru lah sangat penting bagi proses pembelajaran, karena keprofesionalitas lah akan menentukan suatu keberhasilan pada saat proses belajar mengajar di dalam kelas. Sedangkan permasalahan lingkungan dalam faktor penghambat proses pembelajaran biasanya terjadi pada peserta didik yaitu kurangnya minat santri dalam proses pembelajaran. Hal ini karena ditemukan ada beberapa santri pada saat belajar ada yang masih diluar, ketika di dalam kelas masih ada yang ribut, ada juga santri yang usil dengan teman-teman di dalam kelas. Proses meingkatnya di DTA Al-Furqon bisa dilihat dari peserta didik yang masuk setiap tahunnya bertambah.

Sebaiknya pengelolaan sarana dan prasarana lebih ditingkatkan lagi, pada peningkatan proses pembelajaran peserta didik di DTA Al-Furqon Desa Paniis Kec. Pasawahan Kab. Kuningan yang diharapkan dapat membantu peningkatan terhadap kepuasan peserta didik selaku pengguna layanan pendidikan tersebut.

\section{DAFTAR PUSTAKA}

Afriansyah, H. (2019). AdministrasI Sarana dan Prasarana Pendidikan. Padang:osf.io.

Amin Haedar, El-saha Islam. (2004). Peningkatan Mutu Terpadu Pesantren dan Madrasah Diniyah. Jakarta: Diva Pustaka.

Amirullah, 2013. Pengantar Manajemen, Jakarta: Mitra Wacana Media.

Arief, A. (2002) . Pengantar Ilmu dan Metodologi Pendidikan Islam. Jakarta:Ciputat Press

Azwar, S. 2010. Sikap Manusia Teori dan Pengukurannya. Yogyakarta: Pustaka Pelajar Baharuddin. (2010). Psikologi Pendidikan, Yogyakarta: Ar-Ruzz Media.

Baharudin, (2010). Teori Belajar dan Pembelajaran. Yogyakarta: ArRuzz. Media. 
Departemen Agama RI. (2000). Pedoman Penyelenggaraan dan Pembinaan Madrasah Diniyah. Jakarta: Depag.

Fauzi, A. (2017). Manajemen Pendidikan Islam. Yogyakarta: K-Media.

Ibrahim. (1999). Perencanaan Pengajaran. Jakarta: Rineka Cipta.

Ibrahim. (1989). Kurikulum dan Pembelajaran. Jakarta, Kencana.

Ilyas, Yunayar. (2007). Kuliah Akhla. Yogyakarta: Lembaga Pengkajian dan Pengalaman Islam.

Jahari, Jaja \& Amirulloh. (2013). Manajemen Madrasah. Bangung:Alfabeta.

Januartiny. (2015). Administrasi Sarana dan Prasarana

Kartono, K. (1996). Pengantar Metodologi Sosial. Bandung: PT Gramedia.

Kurniawan, A. (2018). Metodologi Penelitian Pendidikan. Bandung: PT Remaja Rosdakarya.

Komsiyah, I. (2012). Belajar dan Pembelajaran. Yogyakarta:Teras.

Matin dan Nurhattati Fuad. 2016. Manajemen Sarana dan Prasarana Pendidikan. Jakarta: Rajawali Pers.

Masyhuri, T. (2018). Pengelolaan Pendidikan Islam Non Formal. Cirebon: CV. Aksarasatu.

Nasirudin, (2010). Pendidikan Tasawuf. Semarang: Rasail Media Group.

Peraturan Pemerintah Republik Indonesia Nomor 55 Tahun 2007, Pendidikan Agama dan Pendidikan Keagamaan dan Pendidikan Keagamaan, Pasal 25, ayat (1).

Prastyawan. (2016). Manajemen Sarana dan Prasarana Pendidikan. Jurnal Studi Keislaman Alhikmah, Vol.6 Nomor.1.

Rusdiana. (2015). Pengelolaan Pendidikan. Bandung: Pustaka Setia.

Sanjaya, W. (2015). Strategi Pembelajaran Berorientasi Standar Pendidikan. Bandung: Kencana.

Sugiyono. (2010). Metodologi Pendidikan. Bandung: Alfabeta.
Sulistyorini. (2009). Manajemen Pendidikan Islam. Yogyakarta : Teras.

Susanto, A. (2016). Teori Belajar dan Pembelajaran. Jakarta: Prenada Media Grup

Soetjipto, Budi. (2008). Paradigma Baru Manajemen Sumber Daya. Yogyakarta: Amara Book.

Sondang P. Siagian. (1974). Administrasi Pendidikan. Jakarta : Gunung Agung.

Sondang P. Siagian. (2008). Manajemen Sumber Daya Manusia. Edisi Pertama. Jakarta: Binapura Aksara.

Tanzeh, A. (2005). Dasar-dasar Penelitian, Surabaya : Elka.

Werang, Basilius R. (2015). Manajemen Pendidikan di Sekolah. Yogyakarta: Media Akademi.

Yamin Martinis dan Maisah. (2009). Manajemen Pembelajaran Kelas Strategi Meningkatkan Mutu Pembelajaran. Jakarta:Gaung Peserda 